\title{
Triathletes' Motivational Dimensions for Participation in Ironman, and Comparison of these Factors with Their Life Satisfaction and Achievement Perceptions
}

\author{
Arif Çetin \\ Faculty of Sport Science, Istanbul Aydin University, Turkey \\ Received September 3, 2019; Revised September 24, 2019; Accepted September 27, 2019
}

Copyright $(2019$ by authors, all rights reserved. Authors agree that this article remains permanently open access under the terms of the Creative Commons Attribution License 4.0 International License

\begin{abstract}
This study aims to examine runners' motivation factors to participate in the Ironman Events and the comparison of these factors with their life satisfaction and success perceptions. The sample of the study were $81,8 \%$ male (n: 112) and $18.2 \%$ female (n: 25) participants who are randomly selected from Ironman Turkey Event in 2018. In the research, "Life Satisfaction Scale"; "Achievement Perception Scale", and "The Motivational Factor Scale for Participating Ultra Marathon" are used as data collection tool in the research. The relations between motivation, life satisfaction and achievement perception are tested with factor analysis, correlation analysis and SEM Partial Least Squares. The results show that motivation has a positive and high relationship with life satisfaction and achievement perception. As a result of the path analysis, there is a significant relationship between motivation dimensions including meaning in life, personal achievement goals and recognition sub-dimensions have a positive and significant effect on life satisfaction. Moreover, health perception has a positive and significant effect on achievement perception. In conclusion, most of the participants were male, the majority of the participants were aged 31 and older and had high income group, university education, working in the private sector, living in the city. It was concluded that the individuals who participated in the Ironman event were individuals who completed their education and worked in the private sector in the business world, who had high income groups and mostly lived in cities. It can be reported that triathletes' high motivational perceptions result in life satisfaction and achievement perception. It can be pointed out that triathletes' high motivational perceptions result in life satisfaction and achievement perception.
\end{abstract}

Keywords Ironman, Triathlete, Motivation Factors, Life Satisfaction, Achievement Perception

\section{Introduction}

It is important to mobilize and motivate individuals for certain purposes. Human instincts lead individuals to act behavior. Only after being motivated can one act to turn behavior into action. Individuals' focus on the purpose stems from motivation [1]. As in all sports, motivation has an important place for triathletes. Activities in difficult conditions such as triathlon are very challenging sport both mentally and physically.

As for the types of motivation, it is possible to classify motivation into three sub-groups as a result of research. These are physiological, mental and social motivation [2]. Physiological requirements, which are at the bottom of Maslow's hierarchy of needs, are the most basic and necessary needs for the survival of the individual. It is difficult to move to the next step without meeting the needs in this category [1]. In order to enable people to act, their basic needs must be met first. Thus, people must satisfy their own needs such as nutrition, resting, dressing and harboring. Therefore, if it is desired to reach a level that can turn into behavior, such needs should firstly be estimated [1]. Social motivation is feelings and thoughts such as belonging to a group, status within the group, admiration, recognition, respect and cooperation. Satisfaction levels rise when people realize their goals [3]. Psychological motivation can be defined as satisfying the psychological needs of people in general. Psychological motives that direct human behavior are social and physiological motives. These motives occur in the spiritual needs of man. One can have these instincts either by birth or later. These motives form behavior and personality models [4].

Achievement is to make an action plan in order to reach a desired goal, to adapt to the conditions of this plan, to make complementary actions specific to the target and to reach their own desires as a result. The concept of achievement is a common concept. This common 
definition applies to individuals, organizations, societies and countries. Achievement is the reach of the intended goal by effectively and efficiently using the available resources. In terms of individuals, the definition of achievement should be added to the individual's ability to cope with negative situations. In addition, the relationships within all these ties in sports, arts and cultural life, work, family and social life are evaluated within the concept of achievement. There are many achievement criteria in sports activities. These criteria such as pleasure received from the activity, skill level developed, getting a point and victories come to the forefront. Achievement and failure are defined as the main element of motivation [5]. Achievement in sporting events can be defined as getting the personal best, breaking world records, winning gold medals and becoming a champion at the international tournaments. Failure can be defined as inability to achieve above them. In addition to this, individuals who are participating in sports as recreational purpose can determine many success criteria such as finishing an ultra-marathon, participating in triathlon events and being an Ironman.

Life satisfaction is the result of comparing the things that one wants to have and what they currently have [6]. Life satisfaction is a result of many factors. These factors are mainly; finding one's own life, current assets, family and work relationships meaningfully, continuing with high satisfaction from daily life, being able to cooperate with others in reaching goals, the ability to create harmony, feeling high morale, positive identity, personal existence and economic assurance [7]. In general, there is a positive relationship between sporting and life satisfaction due to the positive relationship between physical activity or sports and healthy living.

Traditional recreational jogging, cycling and swimming activities are extremely popular in the World. There is also increasing interest and participation in Triathletes' Ironman activities that require intensive physical conditions and mental preparation $[8,9]$.

The Ironman is the longest triathlon event, consisting of $3.8 \mathrm{~km}$ of swimming, $180 \mathrm{~km}$ of cycling and $42,195 \mathrm{~m}$ Marathon, and triathletes must complete this event in less than 17 hours [10].

Every year, thousands of triathletes compete in dozens of Ironman Triathlon races around the world to participate in the Ironman world championship. Ironman Turkey is the biggest Ironman event in Turkey and is held each year in Antalya which is accepted as the tourism capital city of Turkey, where it attracts 1234 finishers including 227 Turkish, and thousands of spectators [11].

Both marathon and triathlon events have become very popular in Turkey in recent years. For instance, Turkey's one of the largest road race events Istanbul Marathon participation $42,195 \mathrm{~m}$ in $2008,15 \mathrm{~km}$ and $10 \mathrm{~km}$ in 7630 , while this number increased to 28286 participants in 2018 [12]. Similarly, triathlon and ironman events are organized in the touristic regions of Turkey such as Belek, Alanya, Kusadasi and Didim. Given the increase in participation in such challenging races, it is important to understand which factors motivate triathlete runners.

Psychological variables of both elite and amateur athletes have significant effects on their performance $[6$, 7]. There have been different approaches to analyze the role of psychological variables in sports performance, and motivation is one of the most important variables in these. Recently, several researchers have investigated the effects of motivation on athletes among these variables $[13,14$, $15,16,17]$. In these studies, researchers have examined the relationship between motivation with performance, motivation with personal image and motivation with physiological characteristics such as gender, age, weight.

This study aims to determine the factors that motivate the Turkish triathletes' participating in the Ironman Turkey Event in 2018 and to compare these factors with their life satisfaction and achievement perception.

Life satisfaction and success perceptions variables stay at the center of the research model. In the study, it was determined that the triathletes' motivation was the main factor affecting these two variables.

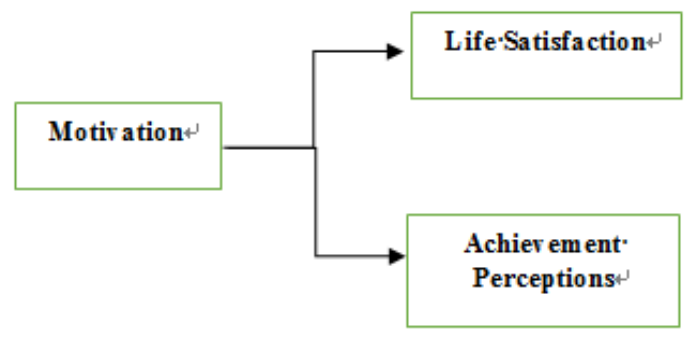

People need to achieve something in their lives. The need for success is related to avoidance of failure and motivation for achievement. Generally, there are two different motives of success among individuals. Motivation to avoid failure can be defined as the state of anxiety and sadness caused by failures, and motivation to succeed can be defined as honor, pride and satisfaction from success [5]. In general, there is a positive relationship between sporting and life satisfaction due to the positive relationship between physical activity or sports and healthy living.

$\mathrm{H}_{1}$ - The motivation sub-dimensions of triathletes who participating in Ironman Event have a positive and significant effect on life satisfaction.

By participating in recreation activities, people gain positive added value in their work and social lives, and they also positively affect their life satisfaction $[18,19]$. In general, there is a positive relationship between sporting and achievement perceptions due to the positive relationship between physical activity or sports and healthy living.

$\mathrm{H}_{2}$ - The motivation sub-dimensions of triathletes who participating in Ironman Event have a positive and significant effect on their achievement perceptions. 


\section{Materials and Methods}

\subsection{Participants}

The sample of this study consisted of 137 triathletes selected by random selection method among 227 Turkish Triathletes who completed the Ironman Turkey Event in 2018. $81.8 \%(\mathrm{n}=112)$ of the participants were male and $18.2 \%(\mathrm{n}=25)$ were female, and $61.3 \%(\mathrm{n}=84)$ of the participants were married. The largest age group was 31 years and older with $81.8 \%(\mathrm{n}=112) ; 48.9 \%(\mathrm{n}=67$ people) of the participants are university graduated. Among the participants, $82.5 \%(\mathrm{n}=113)$ the group of 4000 TRY and over were the most dominant group in terms of monthly income. Moreover, when we look at the number of participants times in the Ironman event so far, the first-time participants are the largest group with 54\% $(\mathrm{n}=74)$, and $49.6 \%(\mathrm{n}=68)$ of the participants were doing sport 6-7 days a week.

\subsection{Procedure}

After Turkish Triathlon Federation approval, triathletes were informed of the objectives and use of the information. Triathletes voluntarily participated in online questionnaire.

\subsection{Measurements}

The In the research, "Life Satisfaction Scale" which is improved by Diener (1985); "Achievement Perception Scale" which is improved by Bilgin and Kaynak (2008), and "The Motivational Factor Scale for Participating in the Ultra Marathon" which is improved by Caliskan (2018) are used as data collection tool in the research.

\subsubsection{Life Satisfaction Scale}

The scale of life satisfaction originally prepared by Diener (1985) was applied. The scale gives an overall judgement of one's life in order to measure the concept of life satisfaction on 7-point Likert scale. This scale that is consists of 5 questions and 1 dimension widely used in social and organizational behavior.

\subsubsection{Achievement Perception Scale}

The scale of achievement perception scale was originally prepared by Bilgin and Kaynak (2008). The scale gives a general perception of success of individuals in order to measure the concept of achievement perception on 7-point Likert scale. This scale that is consists of 4 questions and 1 dimension used in social and organizational behavior.

\subsubsection{Motivational Factor Scale for Participating in the Ultra Marathon}

The scale of achievement perception scale was originally prepared by Caliskan (2018). The scale provides an overview of athletes' motivation levels in order to measure the concept of motivational factor on 5 -point Likert scale. This scale consists of 46 questions and 10 sub-dimensions used in recreational management.

\subsection{Data Analysis}

The validity and reliability of the scale were examined by confirmatory factor analysis. Reflective scales were used for all variables as Kleijnen, Ruyter and Wetzels (2007) studies. To evaluate the psychometric properties of the measurement instruments by using SmartPLS program; a null model without any structural relationship was calculated. Cronbach's Alpha, Composite Reliability (CR) and Average Variance Extracted (AVE) parameters are used to calculate reliability. For all measurements, Cronbach's alpha and PLS based CR values are above the threshold value of 0.70 and AVE values exceed 0.50.

Partial Squares (PLS-Smart 3.0 package program) method was chosen as a method within the scope of "Structural Equation Model" (SEM) to analyze the measurements and structural variables discussed in the research.

\section{Results}

Table 1. Reliability and validity values

\begin{tabular}{|c|c|c|c|c|}
\hline Variables & $\begin{array}{l}\text { No. of } \\
\text { Items }\end{array}$ & $\alpha$ & $\mathrm{CR}$ & AVE \\
\hline Motivational Factor Scale & 46 & & & \\
\hline Socializing & 4 & 0,909 & 0,936 & 0,786 \\
\hline $\begin{array}{l}\text { 2. Competition with } \\
\text { Others }\end{array}$ & 2 & 0,897 & 0,935 & 0,828 \\
\hline Meaning in life & 2 & 0,868 & 0,938 & 0,883 \\
\hline $\begin{array}{l}\text { 4. Competing with } \\
\text { Oneself }\end{array}$ & 3 & 0,894 & 0,948 & 0,902 \\
\hline Weight Control & 3 & 0,890 & 0,929 & 0,813 \\
\hline $\begin{array}{l}\text { Personal } \\
\text { Achievement Goal }\end{array}$ & 4 & 0,849 & 0,908 & 0,768 \\
\hline Self-Respect & 9 & 0,913 & 0,929 & 0,595 \\
\hline $\begin{array}{l}\text { Psychological } \\
\text { Coping }\end{array}$ & 8 & 0,938 & 0,948 & 0,694 \\
\hline 9. Well Being & 5 & 0,912 & 0,935 & 0,741 \\
\hline 10. Recognition & 6 & 0,959 & 0,967 & 0,832 \\
\hline Life Satisfaction Scale & 4 & 0,892 & 0,921 & 0,700 \\
\hline $\begin{array}{l}\text { Achievement Perception } \\
\text { Scale }\end{array}$ & 5 & 0,849 & 0,899 & 0,690 \\
\hline
\end{tabular}

Cronbach's Alpha, Composite Reliability (CR) and Average Variance Extracted (AVE) parameters are used to calculate reliability. For all measurements, Cronbach's alpha and PLS based CR values are above the threshold value of 0.70 and AVE values exceed 0.50. 
Table 2. Factor Loads for Exogenous Variables

\begin{tabular}{|c|c|c|c|c|c|c|c|c|c|c|c|c|}
\hline & Social. & $\begin{array}{c}\text { Comp w } \\
\text { Other }\end{array}$ & Ach. Per. & Mean Life & $\begin{array}{c}\text { Comp w } \\
\text { One. }\end{array}$ & $\begin{array}{c}\text { Weight } \\
\text { Cont }\end{array}$ & $\begin{array}{c}\text { Per Ach } \\
\text { Goal }\end{array}$ & Self-Res & Coping & $\begin{array}{c}\text { Health } \\
\text { Per }\end{array}$ & Recog & $\begin{array}{c}\text { Life } \\
\text { Satis }\end{array}$ \\
\hline aos 1 & 0,808 & & & & & & & & & & & \\
\hline aos2 & 0,917 & & & & & & & & & & & \\
\hline aos 3 & 0,895 & & & & & & & & & & & \\
\hline aos4 & 0,923 & & & & & & & & & & & \\
\hline ba1 & & & 0,751 & & & & & & & & & \\
\hline ba2 & & & 0,767 & & & & & & & & & \\
\hline ba3 & & & 0,893 & & & & & & & & & \\
\hline ba4 & & & 0,901 & & & & & & & & & \\
\hline bir1 & & 0,911 & & & & & & & & & & \\
\hline bir2 & & 0,942 & & & & & & & & & & \\
\hline bir3 & & 0,876 & & & & & & & & & & \\
\hline bkr1 & & & & & 0,965 & & & & & & & \\
\hline bkr2 & & & & & 0,934 & & & & & & & \\
\hline ha1 & & & & 0,935 & & & & & & & & \\
\hline ha2 & & & & 0,945 & & & & & & & & \\
\hline kbh1 & & & & & & & 0,875 & & & & & \\
\hline kbh2 & & & & & & & 0,882 & & & & & \\
\hline kbh3 & & & & & & & 0,872 & & & & & \\
\hline $\mathrm{kk} 1$ & & & & & & 0,875 & & & & & & \\
\hline $\mathrm{kk} 2$ & & & & & & 0,929 & & & & & & \\
\hline kk3 & & & & & & 0,901 & & & & & & \\
\hline os 1 & & & & & & & & 0,832 & & & & \\
\hline os2 & & & & & & & & 0,836 & & & & \\
\hline os 3 & & & & & & & & 0,812 & & & & \\
\hline os 4 & & & & & & & & 0,838 & & & & \\
\hline os 5 & & & & & & & & 0,793 & & & & \\
\hline os6 & & & & & & & & 0,755 & & & & \\
\hline os 7 & & & & & & & & 0,704 & & & & \\
\hline os8 & & & & & & & & 0,644 & & & & \\
\hline os 9 & & & & & & & & 0,703 & & & & \\
\hline pbe1 & & & & & & & & & 0,803 & & & \\
\hline pbe 2 & & & & & & & & & 0,861 & & & \\
\hline pbe3 & & & & & & & & & 0,809 & & & \\
\hline pbe 4 & & & & & & & & & 0,849 & & & \\
\hline pbe 5 & & & & & & & & & 0,852 & & & \\
\hline pbe6 & & & & & & & & & 0,874 & & & \\
\hline pbe 7 & & & & & & & & & 0,796 & & & \\
\hline pbe 8 & & & & & & & & & 0,816 & & & \\
\hline sy1 & & & & & & & & & & 0,838 & & \\
\hline sy2 & & & & & & & & & & 0,886 & & \\
\hline sy3 & & & & & & & & & & 0,919 & & \\
\hline sy4 & & & & & & & & & & 0,893 & & \\
\hline sy 5 & & & & & & & & & & 0,760 & & \\
\hline ts 1 & & & & & & & & & & & 0,872 & \\
\hline ts 2 & & & & & & & & & & & 0,918 & \\
\hline ts 3 & & & & & & & & & & & 0,954 & \\
\hline ts 4 & & & & & & & & & & & 0,954 & \\
\hline ts5 & & & & & & & & & & & 0,933 & \\
\hline ts6 & & & & & & & & & & & 0,835 & \\
\hline yd1 & & & & & & & & & & & & 0,805 \\
\hline $\mathrm{yd} 2$ & & & & & & & & & & & & 0,870 \\
\hline yd3 & & & & & & & & & & & & 0,877 \\
\hline $\mathrm{yd} 4$ & & & & & & & & & & & & 0,863 \\
\hline yd5 & & & & & & & & & & & & 0,762 \\
\hline
\end{tabular}


The standardized loading of the measurements on the relevant concepts was calculated by confirmatory factor analysis (CFA) and it was found that all the measurements tested in convergent validity showed a standardized loading exceeding 0,60 to their factors.

After that, "Pearson Correlation Analysis" was used to examine the relationship between motivation, life satisfaction and success perceptions. The correlations between the variables are given in the table below.

Table 3. Fornell-Larcker and Latent Variable Correlation Values regarding Measurement Model

\begin{tabular}{|l|l|l|l|l|l|l|l|l|l|l|l|l|}
\hline & Social & $\begin{array}{c}\text { Comp } \\
\text { w Other }\end{array}$ & $\begin{array}{c}\text { Ach. } \\
\text { Per. }\end{array}$ & $\begin{array}{c}\text { Mean } \\
\text { Life }\end{array}$ & $\begin{array}{c}\text { Comp } \\
\text { w One. }\end{array}$ & $\begin{array}{c}\text { Weight } \\
\text { Cont }\end{array}$ & $\begin{array}{c}\text { Per Ach } \\
\text { Goal }\end{array}$ & Self-Res & Coping & $\begin{array}{c}\text { Well } \\
\text { Being }\end{array}$ & Recog & $\begin{array}{c}\text { Life } \\
\text { Satis }\end{array}$ \\
\hline Social. & $\mathbf{0 , 8 8 7}$ & & & & & & & & & & \\
\hline $\begin{array}{l}\text { Comp w } \\
\text { Other }\end{array}$ & $0,514^{* *}$ & $\mathbf{0 , 9 1 0}$ & & & & & & & & & \\
\hline Ach. Per. & $0,381^{* *}$ & $0,187^{*}$ & $\mathbf{0 , 8 3 1}$ & & & & & & & & & \\
\hline Mean Life & $0,455^{* *}$ & $0,415^{* *}$ & $0,399^{* *}$ & $\mathbf{0 , 9 4 0}$ & & & & & & & & \\
\hline $\begin{array}{l}\text { Comp w } \\
\text { One. }\end{array}$ & $0,267^{*}$ & $0,298^{* *}$ & $0,341^{* *}$ & $0,633^{* *}$ & $\mathbf{0 , 9 5 0}$ & & & & & & & \\
\hline $\begin{array}{l}\text { Weight } \\
\text { Cont }\end{array}$ & $0,358^{* *}$ & $0,375^{* *}$ & $0,237^{*}$ & $0,322^{* *}$ & $0,231^{* *}$ & $\mathbf{0 , 9 0 2}$ & & & & & & \\
\hline $\begin{array}{l}\text { Per Ach } \\
\text { Goal }\end{array}$ & $0,577^{* *}$ & $0,448^{* *}$ & $0,459^{* *}$ & $0,479^{* *}$ & $0,540^{* *}$ & $0,328^{* *}$ & $\mathbf{0 , 8 7 6}$ & & & & & \\
\hline Self-Res & $0,461^{* *}$ & $0,400^{* *}$ & $0,399^{* *}$ & $0,614^{* *}$ & $0,522^{* *}$ & $0,370^{* *}$ & $0,456^{* *}$ & $\mathbf{0 , 7 7 1}$ & & & & \\
\hline Coping & $0,558^{* *}$ & $0,475^{* *}$ & $0,375^{* *}$ & $0,528^{* *}$ & $0,380^{* *}$ & $0,279^{*}$ & $0,527^{* *}$ & $0,501^{* *}$ & $\mathbf{0 , 8 3 3}$ & & & \\
\hline $\begin{array}{l}\text { Well } \\
\text { Being }\end{array}$ & $0,533^{* *}$ & $0,338^{* *}$ & $0,482^{* *}$ & $0,381^{* *}$ & $0,301^{* *}$ & $0,444^{* *}$ & $0,628^{* *}$ & $0,395^{* *}$ & $0,483^{* *}$ & $\mathbf{0 , 8 6 1}$ & & \\
\hline Recog & $0,505^{* *}$ & $0,634^{* *}$ & $0,234^{*}$ & $0,402^{* *}$ & $0,215^{*}$ & $0,411^{* *}$ & $0,321^{* *}$ & $0,517^{* *}$ & $0,491^{* *}$ & $0,346^{* *}$ & $\mathbf{0 , 9 1 2}$ & \\
\hline Life Satis & $0,233^{*}$ & $0,200^{*}$ & $0,575^{* *}$ & $0,146^{*}$ & $0,267^{*}$ & $0,152^{*}$ & $0,374^{* *}$ & $0,303^{* *}$ & $0,278^{*}$ & $0,287^{*}$ & $0,273^{*}$ & $\mathbf{0 , 8 3 6}$ \\
\hline
\end{tabular}

$*: \mathrm{p}<0,05, * *: \mathrm{p}<0,01$

According to the results in Table 3, there is a positive relationship between all dimensions of motivation, life satisfaction and success perception. Besides, the square root of the AVE values is higher than the correlation pairs. Thus, it can be said that our measurements meet the required validity and reliability criteria.

The following table shows the results of the hypothesis tests, path analysis and structural model of the research.

Table 4. Path Analysis Values Concerning the Structural Model Testing of the Research

\begin{tabular}{|c|c|c|}
\hline & Original Sample ( $\beta$ ) & P Values \\
\hline Socialising-> Achievement Perception & 0,076 & 0,506 \\
\hline Socialising -> Life Satisfaction & $-0,046$ & 0,703 \\
\hline Competition with Others $->$ Achievement Perception & $-0,144$ & 0,172 \\
\hline Competition with Others -> Life Satisfaction & $-0,068$ & 0,576 \\
\hline Meaning in life -> Achievement Perception & 0,123 & 0,344 \\
\hline Meaning in life -> Life Satisfaction & 0,259 & $\mathbf{0 , 0 4 5}$ \\
\hline Competing with Oneself $->$ Achievement Perception & 0,041 & 0,713 \\
\hline Competing with Oneself -> Life Satisfaction & 0,156 & 0,195 \\
\hline Weight Control -> Achievement Perception & $-0,017$ & 0,840 \\
\hline Weight Control -> Life Satisfaction & $-0,037$ & 0,717 \\
\hline Personal Achievement Goal -> Achievement Perception & 0,148 & 0,222 \\
\hline Personal Achievement Goal -> Life Satisfaction & 0,265 & 0,021 \\
\hline Self-Respect $->$ Achievement Perception & 0,131 & 0,223 \\
\hline Self-Respect -> Life Satisfaction & 0,152 & 0,199 \\
\hline Psychological Coping -> Achievement Perception & 0,050 & 0,616 \\
\hline Psychological Coping -> Life Satisfaction & 0,076 & 0,511 \\
\hline Well-being -> Achievement Perception & 0,269 & 0,016 \\
\hline Well-being -> Life Satisfaction & 0,070 & 0,537 \\
\hline Recognition $->$ Achievement Perception & 0,003 & 0,979 \\
\hline Recognition $->$ Life Satisfaction & $\mathbf{0 , 2 0 0}$ & 0,048 \\
\hline
\end{tabular}


As shown in the table, the results confirm some of the research hypotheses. Motivation Dimensions including meaning in life ( $\boldsymbol{\beta}: \mathbf{2 5 9}, \mathbf{p}<\mathbf{0 , 0 5})$, personal achievement goals $(\boldsymbol{\beta}: \mathbf{2 6 5}, \mathbf{p}<\mathbf{0 , 0 5})$ and recognition $(\boldsymbol{\beta}: \mathbf{2 0 0}, \mathbf{p}<\mathbf{0 , 0 5})$ sub-dimensions have a positive and significant effect on life satisfaction. Moreover, health perception, which is one of the motivation dimensions, has a positive and significant effect on achievement perception $(\boldsymbol{\beta}: \mathbf{2 6 9}, \mathbf{p}<\mathbf{0 . 0 5})$.

Table 5. Model Fit Summary

\begin{tabular}{|c|c|c|c|}
\hline \multicolumn{4}{|c|}{ Model Fit } \\
\hline $\mathbf{R}^{\mathbf{2}}$ & $\begin{array}{c}\text { Endogenous } \\
\text { Variables }\end{array}$ & $\begin{array}{c}\text { Compliance } \\
\text { Index }\end{array}$ & \\
\hline 0,330 & $\begin{array}{c}\text { Achievement } \\
\text { Perception }\end{array}$ & NFI & 0,745 \\
\hline 0,215 & $\begin{array}{c}\text { Life } \\
\text { Satisfaction }\end{array}$ & Chi-square & $2.837,725$ \\
\hline & & SRMR & 0,075 \\
\hline
\end{tabular}

The structural model showed that the model explains 33\% of the change in Achievement Perception and $21.5 \%$ of the change in life satisfaction. NFI was calculated as 0,745 in Model Fit. The model appears to be within acceptable limits within this ratio. SRMR value should be less than 0.08 . The SRMR value for this model was calculated as 0.050 , again indicating that the model provides the necessary threshold value. Our chi-square value was calculated as 2.837,725. Therefore, our model is considered as an "acceptable model" from the point of fit indices.

\section{Discussion}

This study has explored the factors that motivate the athletes participating in the Ironman Turkey Event in 2018 and compared these factors with their life satisfaction and achievement perception. The results of this study have shown that motivation has a positive and high relationship with life satisfaction and achievement perception. As a result of the path analysis, there is a significant relationship between motivation sub-dimensions including meaning in life, personal achievement goals and recognition sub-dimensions have a positive and significant effect on life satisfaction. Moreover, well-being has a positive and significant effect on achievement perception.

Individuals with low incomes are more likely to prefer group activities. As income increases, individuals with low incomes are more likely to prefer group activities. As income increases, individuals prefer more high-cost recreational activities and they also prefer to participate alone [2]. The results obtained in this study support these findings. Triathletes require high income in order to cover expenses such as nutrition, clothing, special equipment for running, swimming and cycling, accommodation, camping and training expenses of individuals during preparation periods.
Variables such as meaning of life, well-being and recognition can be evaluated within the framework of Maslow's Hierarchy of Needs [20]. In particular, it can be said that high-income individuals prefer Ironman Events to realize meaning of life, well-being and recognition. In addition, personal achievement motivation can be evaluated in An Achievement Goal Theory [21]. It can be explained with Task Setting Goals in sports events such as Ironman, which is a form of championship where individuals compete with themselves and with others.

In the study, the reason that there was no relationship between other motivation sub-dimensions and life satisfaction and achievement perception may be that the participants wanted to compete with them significantly. This may be due to the fact that triathletes would like to improve their personal best in each Ironman Events and to improve themselves by constantly competing with themselves in more difficult courses or competitions in different places.

It can be said that the perception of success and life satisfaction increases as triathletes' motivation to participate in the marathon increases. The findings of the study were supported by several researches [22, 23, 24]. This research article can contribute to the existing literature in four ways.

The first outcome of our study is the relationship between meaning in life and life satisfaction. Participants who feel high perceived meaning in life also can have positive relation with life satisfaction literature [25]. The result of the study was supported by other researches. [26, 27. 28]. This result showed that meaning in life is a key component of life satisfaction among triathletes.

The second outcome of the study is the positive relationship between personal achievement goals and life satisfaction. Individuals with achievement goals can show high motivation when faced with any challenge in their social lives (Grant and Dweck, 2003). The study found that personal achievement goals showed a positive correlation with life satisfaction. These findings are consistent with many findings in the literature $[25,30,31,32]$.

The third outcome of the study is a positive relationship between recognition and life satisfaction. The power of recognition and life satisfaction not only present to affect the ideal functioning of a person in the but also willingness to encourage positive progression in near future [32]. This result was coincided with other findings [33, 34]. Recognition appears to be a key factor affecting life satisfaction and it seems to be effective in helping triathletes change and improve their lives positively.

The fourth outcome of the study is a positive relationship between well-being and achievement perception. Many studies have been conducted between these two variables in the literature. This result was coincided with several [35, $36,37,38,39]$. 


\section{Conclusions}

Most of the participants were male, the majority of the participants were aged 31 and older and had high income group, university education, working in the private sector, living in the city. It was concluded that the individuals who participated in the Ironman event were individuals who completed their education and worked in the private sector in the business world, who had high income groups and mostly lived in cities.

As a result, the motivation dimensions of triathletes participating in the Ironman Event had a positive and significant effect on life satisfaction and achievement perceptions. Furthermore, the relationship between motivation sub-dimensions including meaning in life, personal achievement goals and recognition sub-dimensions have a positive and significant effect on life satisfaction. Also, well-being has a positive and significant effect on achievement perception. This research article provides an overall approach about sub-dimensions of motivation, life satisfaction and achievement goals which are abstractly conducive and important for practice.

\section{REFERENCES}

[1] B. Dur. Lise öğretmenlerinin motivasyon düzeyi ve motivasyon düzeyi ile okul kültürü arasındaki ilișki. İstanbul Aydin Universitesi Sosyal Bilimler Enstitüsü, Yüksek Lisans Tezi, İstanbul, 2014.

[2] A. Çalıșkan, Kișileri ultra maraton koşmaya motive eden faktörler ölçeğinin geliştirilmesi ve bu faktörlerin katılımcıların yaşam doyumları ve başarı algılarıyla karşılaştırılması (Yayımlanmış Yüksek Lisans Tezi). Akdeniz Üniversitesi, Sağlık Bilimleri Enstitüsü, Hareket ve Antrenman Anabilim Dalı, Antalya, 2018.

[3] Z. Sabuncuoğlu Z, M. Tuz. Örgütsel psikoloji. 1. Bask1. Bursa: Alfa Basın Yayın Dağıtım; 1998.

[4] F. Taspinar. Motivasyon araçlarının isgoren motivasyonu üzerindeki etkisi: afyonkarahisar ilindeki termal otel isletmelerinde bir arastirma. A.K.Ü. Sosyal Bilimler Entitüsü, Yüksek Lisans Tezi. 2006.

[5] S. Bozkurt. Okul Sporlarına Katılan Öğrencilerin Katılım Motivasyonu, Spor BaĢarı Algısı ve Öz Yeterliklerinin Incelenmesi. Akdeniz Universitesi Saglik Bilimleri Enstitüsü, Yuksek Lisans Tezi, 2014.

[6] B. Altay, I. Avcı. Huzurevinde yaşayan yaşlilarda özbakım gücü ve yaşam doyumu arasındaki iliski. Dicle Tıp Dergisi. $36 ; 4 ; 275-282,2009$.

[7] F. Ardahan. Bireyleri Rekreatif Spor Etkinliklerine Motive Eden Faktörlerin Remm Olçegini Kullanarak Çesitli Demografik Degişkenlere Gore Incelenmesi: Antalya Ornegi. Pamukkale Journal of Sport Sciences, 4:1-15, 2013.

[8] M.D. Hoffman, J.C. Ong, G. Wang. Historical analysis of participation in $161 \mathrm{~km}$ ultramarathons in north America.
International Journal of History Sport, 27(11):1877-1891, 2010.

[9] S. Hughes, H.S., Case, Stuempfle, K. Evans, D., Personality profiles of iditasport ultra-marathon participants, Journal Apply Sport Psychology, 15(3): 256-261, 2003.

[10] E. Myburgh, M. Kruger, M. Saayman. A motivation-based typology of triathletes, South African Journal for Research in Sport, Physical Education and Recreation, 36: 117-134, 2014.

[11] Maraton.istanbul, Online available from https://www.marat on.istanbul/kopyasi-sonuclar-1 Accessed: 28.07.2019.

[12] Ironman.com, Online available from https://www.ironman.c om/de-at/triathlon/events/emea/ironman-70-3/turkey/result s.aspx Accessed: 28.07.2019.

[13] A. Macnamara, A. Button, D. Collins. The role of psychological characteristics in facilitating the pathway to elite performance part 1: identifying mental skills and behaviors, The Sport Psychologist, 24(1):52-73, 2010.

[14] C. Swann, L. Crust, S. A. Vella. New directions in the psychology of optimal performance in sport: flow and clutch states, Current Opinion in Psychology, 16, 48-53, 2017.

[15] J. Havenar, M. Lochbaum. Differences in participation motives of first-time marathon finishers and pre-race dropouts, Journal of Sport Behavior, 30: 270-279, 2007.

[16] S.G. Ziegler. Perceived benefits of marathon running in males and females, Sex Roles, 25: 119-27, 1991.

[17] R.O. Deaner, K.S. Masters, B.M. Ogles, R.A. La Caille. Marathon performance as a predictor of competitiveness and training in men and women, Journal of Sport Behaviour, 34: 325-42, 2011.

[18] D.A. Baker, R.J. Palmer. Examining the Effects of Perceptions of Community and Recreation Participation on Quality of Life. Social Indicators Research, 75:395-418, 2006.

[19] T. Toros, U. Akyüz, M. Bayansalduz, F. Soyer. Gorev ve ego yonelimli hedeflerin yasam doyumu ile iliskisinin incelenmesi, dagcılık sporu yapanlarla ilgili bir çalısma, Uluslararası Insan Bilimleri Dergisi, 7:1039-1050, 2010.

[20] H. Ibrahim, K.A. Cordes KA. Outdoor Recreation, Enrichment for a Lifetime. Second Edition. Sagamore Publishing, 1:5-150, 2002.

[21] P. R. Pintrich. An achievement goal theory perspective on issues in motivation terminology. Theory and Research, Contemporary Educational Psychology, 25:92-104, 2000.

[22] G.C. Roberts. Motivation in sport and exercise from an achievement goal theory perspective: after 30 years, where are we? In: Roberts GC, Treasure DC (eds) Advances in Motivation in Sport and Exercise, 3rd edition. Human Kinetics, Champaign, 5-58: 2012.

[23] C. H. Sit, K. J. Lindner. Situational state balances and participation motivation in youth sport; a reversal theory perspective, British Journal of Educational Psychology, 76: 369-384, 2006.

[24] A. Çetin, C. Özman. Koşucularin ultra-maraton 
etkinliklerine katilmalarindaki motivasyonel boyutlar ve bu boyutlarin onlarin yaşam doyumlari ve başari algilariyla karşilaştirilmasi”, Spormetre Beden Eğitimi ve Spor Bilimleri Dergisi, 17(2): 177-187, 2019.

[25] M. Sato, J.S. Jordan, D.C. Funk. Distance running events and life satisfaction: a longitudinal study. Journal of Sport Management, 29(4): 347-361, 2015.

[26] J.E. Mahan, W.J. Seo, J.S. Jordan, D. Funk. Exploring the impact of social networking sites on running involvement, running behavior, and social life satisfaction. Sport Management Review, 18(2): 182-192, 2015.

[27] W. Wang, J. Li, G. Sun, Z. Cheng, X. Zhang. Achievement goals and life satisfaction: The mediating role of perception of successful agency and the moderating role of emotion reappraisal. Psicologia: Reflexão E Crítica, 30(1): 2017.

[28] N. Park, M. Park, C. Peterson. When is the Search for Meaning Related to Life Satisfaction? Applied Psychology: Health and Well-Being, 2(1): 1-13, 2010.

[29] M.F. Steger, P. Frazier, S. Oishi, M. Kaler. The meaning in life questionnaire: Assessing the presence of and search for meaning in life, Journal of Counseling Psychology, 53, (1): 80-93, 2006.

[30] C.A. Bonebright, D.L. Clay, R.D. Ankenmann. The relationship of workaholism with work-life conflict, life satisfaction, and purpose in life. Journal of Counseling Psychology, 47, (4): 469-477, 2000.

[31] H. Grant, C.S. Dweck. Clarifying achievement goals and their impact. Journal of Personality and Social Psychology, 85(3): 541-553, 2003.

[32] C. Senko, J.M. Harackiewicz. Achievement goals, task performance, and interest: why perceived goal difficulty matters. Personality and Social Psychology Bulletin, 31(12): 1739-1753, 2005.

[33] F. K. Lee, K. M. Sheldon, D. B. Turban. Personality and the goal-striving process: the influence of achievement goal patterns, goal level and mental focus on performance and enjoyment. Journal of Applied Psychology, 88:256-265, 2003.

[34] C. R. Stevic, R. M. Ward, Initiating Personal Growth: The Role of Recognition and Life Satisfaction on the Development of College Students. Social Indicators Research, 89(3): 523-534, 2008.

[35] S. Chen, S. Lin, Q. Ruan, H. Li, S. Wu. Workplace violence and its effect on burnout and turnover attempt aong Chinese medical staff. Archives of Environmental \& Occupational Health, 71(6): 330-337, 2015.

[36] S. Bücker, S. Nuraydin, B.A. Simonsmeier, M. Schneider, M. Luhmann. Subjective well-being and academic achievement: A meta-analysis. Journal of Research in Personality, 74: 83-94, 2018.

[37] L. Yu, D.T.L. Shek, X. Zhu. The influence of personal well-being on learning achievement in university students over time: mediating or moderating effects of internal and external university engagement. Frontiers in Psychology, 8, 2018 .

[38] E. Randell, L. Jerden, A. Öhman, R. Flacking. What is health and what is important for its achievement? a qualitative study on adolescent boys' perceptions and experiences of health. The Open Nursing Journal, 10(1): 26-35, 2016.

[39] Y. Bakir, M. Kangalgil. The effect of sport on the level of positivity and well-being in adolescents engaged in sport regularly. Journal of Education and Training Studies, 5(11): 98, 2017. 